\title{
PENERAPAN METODE ACTIVE KNOWLEDGE SHARING BERBANTU MEDIA TEKA TEKI SILANG UNTUK MENINGKATKAN AKTIVITAS BELAJAR
}

\section{IMPLEMENTATION OF ACTIVE KNOWLEDGE SHARING ASSISTED BY CROSSWORD PUZZLE TO IMPROVE STUDENT LEARNING ACTIVITY}

\author{
Oleh: \\ Agatha Saputri \\ Pendidikan Akuntansi Universitas Negeri Yogyakarta \\ agathasaputri87@gmail.com
}

Sukirno

Staf Pengajar Jurusan P. Akuntansi Universitas Negeri Yogyakarta

\begin{abstract}
Abstrak
Penelitian ini merupakan Penelitian Tindakan Kelas (Classroom Action Research) yang bertujuan untuk meningkatkan Aktivitas Belajar pada Kompetensi Akuntansi Perusahaan Jasa Siswa Kelas XII SMA Negeri 1 Wonosari Tahun Ajaran 2015/2016 melalui Penerapan Metode Active Knowledge Sharing Berbantu Media Teka Teki Silang. Penelitian ini dilaksanakan secara kolaboratif selama tiga siklus. Analisis data yang digunakan yaitu analisis data deskriptif dengan persentase. Berdasarkan hasil penelitian, diperoleh kesimpulan bahwa Penerapan Metode Active Knowledge Sharing dapat meningkatkan aktivitas belajar siswa kelas XII Matematika dan Ilmu Alam 1 SMA Negeri 1 Wonosari Tahun Ajaran 2015/2016. Hal ini ditunjukkan dengan data penelitian yang menunjukkan adanya peningkatan pada semua indikator Aktivitas Belajar Siswa dari siklus I sebesar $67,08 \%$ meningkat menjadi $83,92 \%$ pada siklus II dan diperkuat meningkat menjadi $86 \%$ pada siklus III. Berdasarkan data catatan harian menunjukkan perubahan positif sikap siswa terhadap Penerapan Metode Active Knowledge Sharing.
\end{abstract}

Kata kunci: Metode Active Knowledge Sharing, Teki Teki Silang

\begin{abstract}
This research was a Classroom Action Research. The objective of this research was to improve Learning Activities of Grade XII students on Competence of Accounting Service Company at SMA Negeri 1 Wonosari in the academic year of 2015/2016 through Active Knowledge Sharing assisted by crossword puzzle. Researcher and teacher worked collaboratively in doing the classroom action research consisted of three cycles. The data were analyzed using descriptive analysis data. The result of this research showed that the use of Active Knowledge Sharing was successful to improve lerning activities the XII Matematika dan Ilmu Alam 1 students of SMA Negeri 1 Wonosari in the academic year of 2015/2016. This was indicated by the research data that showed an increase in all indicators of students learning activities in the first cycle of 67,08\% increased to $83,92 \%$ in the second cycle and it was strengthened increased to $86 \%$ in the third cycle. Based on field notes, it showed that there was positive alteration to the use of Active Knowledge Sharing.
\end{abstract}

Keywords: Active Knowledge Sharing, Crossword Puzzle

\section{PENDAHULUAN}

Akuntansi merupakan mata pelajaran yang berisi tentang angka-angka sehingga untuk memahaminya dibutuhkan konsentrasi yang tinggi. Materi dalam mata pelajaran Akuntansi saling berkaitan satu sama lain. Jika siswa tertinggal satu pokok bahasan dalam mata pelajaran akuntansi maka siswa 
tersebut akan tertinggal dan kesulitan memahami pokok bahasan yang selanjutnya. Sehingga siswa dituntut berkonsentrasi dalam mata pelajaran ini. Namun pada kenyataannya rata-rata siswa merasa kesulitan dalam memahami dan mengikuti materi yang diajarkan oleh guru ketika sudah selang beberapa waktu jam pelajaran akuntansi berjalan. Siswa berkonsentrasi tinggi ketika berada di awal jam kegiatan belajar mengajar namun apabila sudah berjalan beberapa waktu maka konsentrasi siswa akan berkurang, padahal mata pelajaran akuntansi menuntut siswa untuk selalu berkonsentrasi pada semua pokok bahasan yang dijelaskan secara runtut. Siswa kesulitan memahami materi mata pelajaran akuntansi karena dianggap sulit. Peneliti mengetahui hal ini dengan melakukan observasi saat kegiatan belajar mengajar akuntansi. Dampak dari hal tersebut adalah siswa menjadi tertinggal beberapa materi yang seharusnya dipahami. Guru kurang kreatif dalam menerapkan metode-metode pembelajaran sehingga siswa cepat merasa bosan jika hanya berisi teori-teori saja. Karena mengejar agar materi yang diajarkan cepat selesai maka sering kali guru melupakan bahwa dalam mengajar guru juga harus memberikan motivasi kepada siswa pada saat pembelajaran.Guru kurang menarik dalam menyampaikan materi sehingga siswa cepat merasa bosan akan materi yang diajarkan. Dengan materi yang menuntut konsentrasi diperlukan metode pembelajaran yang menarik. Dalam penyampaian guru acap kali menjelaskan secara cepat tanpa memberikan selingan motivasi dan pentingnya mempelajari pokok bahasan akuntansi. Padahal idealnya dalam proses belajar mengajar siswa juga harus berperan aktif, baik dalam hal bertanya maupun memberikan pendapat terkait dengan pokok bahasan Akuntansi.

Melihat kenyataan tersebut, pada pembelajaran Akuntansi berikutnya sudah sewajarnya dirancang suatu model pembelajaran Akuntansi yang menarik dan menyenangkan dengan berbantu media permainan. Dalam mengajar, guru tidak hanya berceramah saja tetapi juga menerapkan metode pembelajaran aktif, menggunakan permainan dalam menjelaskan materi, memberi motivasi, mengajukan pertanyaan kepada siswa, meminta pendapat dari siswa, dll. Mengajar bukan hanya penyampaian informasi dari guru kepada siswa saja, melainkan juga membutuhkan keterlibatan mental dan tindakan siswa itu sendiri. Proses belajar aktif akan membuat siswa bertahan lama berada di kelas, karena pada saat kegiatan belajar aktif, maka siswa akan turut ambil bagian dalam berpikir mengenai materi yang sedang diajarkan. Siswa menggunakan dan mengasah pikiran untuk mempelajari gagasan-gagasan, memecahkan berbagai masalah, dan menerapkan apa yang dipelajari tidak sekedar mendengarkan guru menyampaikan materi saja. Hamruni (2012: 155) mengemukakan hal yang sangat penting dalam aktivitas belajar aktif adalah bahwa para siswalah yang melakukan kegiatan belajar, merekalah yang harus mencari dan memecahkan masalah sendiri, menemukan contoh-contoh, mencoba keterampilanketerampilan, dan melakukan tugas-tugas pembelajaran yang harus dicapai. Untuk mewujudkan proses belajar aktif maka guru dan siswa harus berperan aktif. Salah satu upaya menciptakan pembelajaran yang aktif dan menyenangkan adalah dengan metode Active Knowledge Sharing dan dibantu dengan penggunaan media Teka Teki Silang. Dengan penerapan metode Active Knowledge Sharing maka siswa dapat berperan aktif dalam pembelajaran dan dibantu dengan penggunaan media Teka Teki Silang ini guru dapat mengajak siswa untuk menebak, berpikir, dan menemukan jawaban tepat yang berkaitan dengan materi yang sedang dibahas dalam pembelajaran. Dengan metode ini guru mengajak siswa untuk menganalisis materi dan berperan aktif dalam sharing. Memberikan motivasi, meminta pendapat siswa, dan menjawab pertanyaan dari siswa dapat dilakukan dengan metode pembelajaran ini. 
Berdasarkan observasi awal yang dilakukan pada bulan Agustus tahun 2015 di kelas XII Matematika dan Ilmu Alam 1 SMA Negeri 1 Wonosari menunjukkan bahwa aktivitas belajar akuntansi masih rendah. Terdapat 20 siswa atau $67 \%$ siswa masih pasif dalam pembelajaran. Dalam hal ini siswa ada yang mengobrol dengan temannya, diam saja, bermain gadget, dan kurang memperhatikan guru. Hal tersebut dapat disebabkan salah satunya karena model pembelajaran yang digunakan oleh guru kurang menarik yaitu metode ceramah. Padahal idealnya, dalam kegiatan belajar mengajar bukan hanya guru yang aktif tetapi siswa juga aktif. Penggunaan model pembelajaran yang tidak sesuai dengan minat siswa, akan menyebabkan siswa tidak memperhatikan guru yang sedang menerangkan materi pelajaran dan hal tersebut berdampak pada kurangnya aktivitas belajar siswa dan prestasi belajar akuntansi yang belum maksimal.

Dari uraian di atas, dapat disimpulkan bahwa model pembelajaran guru yang kurang variatif dapat menimbulkan rendahnya aktivitas belajar siswa. Hal tersebut terjadi karena guru terlalu banyak menggunakan metode ceramah. Dengan penerapan metode Active Knowledge Sharing dibantu dengan penggunaan media Teka Teki Silang ini diharapkan dapat meningkatkan aktivitas belajar akuntansi siswa. Untuk itu, peneliti melakukan penelitian dengan judul "Penerapan Metode Active Knowledge Sharing Berbantu Media Teka Teki Silang untuk Meningkatkan Aktivitas Belajar pada Kompetensi Akuntansi Perusahaan Jasa Siswa Kelas XII SMA Negeri 1 Wonosari Tahun Ajaran 2015/2016".

Oemar Hamalik (2003: 171) mengemukakan Pengajaran yang efektif adalah pengajaran yang menyediakan kesempatan belajar sendiri atau melakukan aktivitas sendiri. Dewasa ini aktivitas belajar lebih ditekankan melalui suatu program unit activity, sehingga kegiatan belajar siswa menjadi dasar untuk mencapai tujuan dan hasil belajar yang lebih memadai. Aktivitas belajar adalah aktivitas yang bersifat fisik maupun mental. Dalam proses belajar kedua aktivitas ini harus saling berkaitan. Lebih lanjut lagi Piaget (dalam Sardiman A.M, 2011: 100) bahwa jika seorang anak berpikir tanpa berbuat sesuatu, berarti anak itu tidak berpikir. Dari pendapat beberapa ahli, dapat disimpulkan bahwa aktivitas belajar adalah aktivitas yang bersifat fisik dan mental dalam kegiatan belajar mengajar untuk mewujudkan pengajaran yang efektif.

Metode Active Knowledge Sharing ialah salah satu metode pembelajaran aktif. Metode Active Knowledge Sharing ini masuk dalam pembelajaran aktif karena metode Active Knowledge Sharing melatih keaktifan siswa dalam proses kegiatan belajar mengajar sehingga peserta didik mampu mengubah tingkah lakunya secara efektif dan efisien dalam kehidupan mereka sehari-hari. Menurut Zainal Arifin \& Adhi Setiyawan (2012: 63) Active Knowledge Sharing berarti saling tukar pengetahuan. Strategi ini dapat digunakan untuk melihat tingkat kemampuan peserta didik, di samping untuk membentuk kerja sama tim. Strategi ini dapat dilakukan pada hampir semua mata pelajaran. Strategi ini mendorong semua peserta didik aktif dan berani mengungkapkan pendapatnya. Keberhasilan strategi ini tergantung kerja sama tim dalam tukar pengetahuan dengan temannya. Menurut Hamruni (2012: 172) Active Knowledge Sharing merupakan sebuah cara yang bagus untuk menarik para peserta didik kepada materi pelajaran. Strategi ini dapat digunakan untuk mengukur tingkat pengetahuan para peserta didik, pada saat yang sama, melakukan beberapa bangunan tim (team building). Strategi ini bekerja dengan beberapa pembelajaran dan dengan beberapa materi pembelajaran. Dari pengertian Active Knowladge Sharing yang diungkapkan oleh beberapa ahli tersebut, dapat disimpulkan bahwa pengertian Active Knowladge Sharing adalah metode yang dapat digunakan untuk meningkatkan aktivitas belajar siswa 
terhadap materi pelajaran dengan cara bertukar pengetahuan sehingga siswa dapat mengemukakan pendapat dan lebih terfokus kepada materi.

Teka teki silang adalah permainan menebak kata dalam kotak-kotak bujur sangkar kecil yang sudah diisi kata kunci (Heru Kurniawan, 2015: 30). Media pembelajaran teka teki silang adalah sebuah permainan yang dimainkan dengan cara mengisi ruang-ruang kosong yang berbentuk kotak dengan huruf-huruf maupun angka sehingga membentuk sebuah kata maupun susunan angka yang sesuai dengan petunjuk yang dapat menyalurkan pesan dari guru sehingga siswa memperoleh pengetahuan, keterampilan, dan sikap.

Penelitian ini mengacu pada tiga penelitian yang relevan. Hasil penelitian yang dilakukan oleh Yesi Amnesti, Program Studi Pendidikan Guru Sekolah Dasar, Fakultas Kegunaan dan Ilmu Pendidikan, Universitas Muhammadiyah Surakarta (2013) yang berjudul "Penerapan Metode Active Knowledge Sharing untuk Meningkatkan Motivasi Belajar IPA Kelas IV Sekolah Dasar Negeri 03 Ngargoyoso Kabupaten Karanganyar Tahun Pelajaran 2012/2013". Hasil penelitian tersebut menunjukkan adanya peningkatan motivasi belajar siswa dalam pembelajaran IPA yang terlihat dalam 7 indikator.: yaitu indikator memperhatikan guru yang sedang mengajar, menyatakan pendapat dan merumuskan jawaban, mendengarkan dengan baik penjelasan guru, mencatat penjelasan dari guru dengan lengkap dan rapi, merespon dan mengajukan pertanyaan, mengingat materi dan mampu memecahkan masalah, keberanian dalam menyampaikan pendapat, kelemahan dari penelitian ini belum menggunakan media, hanya penerapan metode pembelajaran saja. Kaitannya dengan penelitian saya yaitu sama-sama menggunakan metode Active Knowledge Sharing. Adapun kelebihan penelitian yang peneliti lakukan dibandingkan dengan penelitian ini yaitu peneliti mencoba untuk menggunakan media teka teki silang. Hasil penelitian yang dilakukan oleh Fenti Noor Endah Kurniawati, Program Studi Pendidikan Akuntansi, Fakultas Ekonomi, Universitas Negeri Yogyakarta (2014) yang berjudul "Implementasi Model Active Learning dengan Teknik Learning Starts With A Question untuk Meningkatkan Aktivitas Belajar Akuntansi Peserta Didik Kelas XI IPS 3 SMA Negeri 5 Yogyakarta Tahun Ajaran 2013/2014”. Hasil penelitian menunjukkan bahwa Implementasi Model Active Learning dengan Teknik Learning Starts With A Question dapat Meningkatkan Aktivitas Belajar Akuntansi Peserta Didik Kelas XI IPS 3 SMA Negeri 5 Yogyakarta Tahun Ajaran 2013/2014. Hal ini dibuktikan dengan data penelitian yang menunjukkan adanya peningkatan pada semua indikator Aktivitas Belajar Akuntansi peserta didik. Kelemahan dari penelitian ini yaitu belum menggunakan media dalam pembelajaran. Kaitannya dengan penelitian saya yaitu sama-sama menggunakan salah satu metode pembelajaran Active Learning dan untuk meningkatkan aktivitas belajar. Adapun kelebihan penelitian yang peneliti lakukan dibandingkan dengan penelitian ini yaitu peneliti menerapakan salah satu metode Active Learning yaitu metode Active Knowledge Sharing dan dibantu dengan media teka teki silang sehingga peningkatan aktivitas belajar dapat tercapai. Hasil penelitian yang dilakukan oleh Ika Nursanti, Program Studi Pendidikan Akuntansi, Fakultas Ekonomi, Universitas Negeri Yogyakarta (2014) yang berjudul "Implementasi Metode Pembelajaran Kooperatif Tipe Teams Games Tournament (TGT) dengan Media Teka Teki Silang untuk Meningkatkan Aktivitas Belajar Akuntansi Siswa Kelas X Akuntansi SMK Kristen 2 Klaten Tahun Ajaran 2013/2014". Berdasarkan hasil penelitian, diperoleh kesimpulan bahwa Implementasi Metode Pembelajaran Kooperatif Tipe Teams Games Tournament (TGT) dapat meningkatkan aktivitas belajar akuntansi siswa kelas $\mathrm{X}$ Akuntansi SMK Kristen 2 Klaten Tahun Ajaran 2013/2014. Hal ini ditunjukkan 
dengan meningkatnya aktivitas belajar akuntansi siswa dari siklus I sebesar $67,48 \%$ meningkat menjadi $81,77 \%$ pada siklus II. Berdasarkan hasil wawancara dan angket yang telah dilakukan terhadap siswa menunjukkan respon yang positif terhadap Penerapan Metode Pembelajaran Kooperatif Tipe Teams Games Tournament (TGT). Siswa merasa senang dengan adanya penerapan metode pembelajaran kooperatif tersebut karena menciptakan suasana pembelajaran yang baru. Siswa menjadi tidak cepat bosan dan mengantuk selama mengikuti pembelajaran karena melalui metode pembelajaran tersebut siswa dikondisikan untuk aktif. Kaitannya dengan penelitian ini yaitu sama-sama menggunakan media teka teki silang dan untuk meningkatkan aktivitas belajar akuntansi siswa. Adapun kelebihan penelitian yang peneliti lakukan dibandingkan dengan penelitian ini yaitu peneliti menerapkan metode Active Knowledge Sharing untuk meningkatkan aktivitas belajar siswa.

Proses pembelajaran akuntansi pada kelas XII Matematika dan Ilmu Alam 1 SMA Negeri 1 Wonosari Tahun Ajaran 2015/2016 mempunyai keaktifan belajar yang belum maksimal. Dari hasil observasi terdapat 20 siswa atau sekitar $67 \%$ siswa masih pasif. Dalam hal ini siswa ada yang mengobrol dengan temannya, diam saja, bermain gadget, dan kurang memperhatikan guru. Hal ini menunjukkan adanya permasalahan dalam proses pembelajaran. Menghadapi permasalahan aktivitas belajar yang masih rendah tersebut, perlu adanya perbaikan dalam proses pembelajaran. Memberikan dorongan atau menarik perhatian siswa, memberikan stimulus, menyimpulkan setiap materi yang disampaikan di akhir pekan, dan melakukan tagihan-tagihan kepada siswa berupa tes dapat mempengaruhi munculnya aktivitas belajar. Metode pembelajaran dan media yang bervariasi dapat menarik perhatian siswa, sehingga siswa aktif dalam kegiatan pembelajaran. Guru lebih aktif menjelaskan materi dan latihan soal selama kegiatan belajar mengajar berlangsung. Dengan metode pembelajaran yang kurang variatif tersebut dapat menimbulkan rendahnya aktivitas belajar siswa. Oleh karena itu, perlu penerapan metode pembelajaran aktif dan media yang menarik sehingga aktivitas belajar siswa akan meningkat. Salah satu metode pembelajaran aktif dalam proses pembelajaran yaitu metode Active Knowledge Sharing dengan dibantu media teka teki silang sehingga dapat menciptakan pembelajaran yang aktif, oleh karena itu peneliti tertarik untuk melaksanakan penelitian dengan judul "Penerapan Metode Active Knowledge Sharing berbantu Media Teka Teki Silang untuk meningkatkan aktivitas belajar akuntansi pada Kompetensi Akuntansi Perusahaan Jasa Siswa Kelas XII SMA Negeri 1 Wonsari Tahun Ajaran 2015/2016".

Tujuan penelitian ini adalah untuk meningkatkan Aktivitas Belajar pada Kompetensi Akuntansi Perusahaan Jasa Siswa Kelas XII SMA N 1 Wonosari Tahun Ajaran 2015/2016 dengan metode Active Knowledge Sharing berbantu media Teka Teki Silang.

\section{METODE PENELITIAN}

Penelitian ini merupakan penelitian tindakan kelasa yang dilakukan (Classroom Action Research). Peneliti melakukan secara kolaboratif dan partisipatif, artinya peneliti tidak melakukan penelitian ini sendiri melainkan bekerjasama dengan guru mata pelajaran Akuntansi SMA Negeri 1 Wonosari. Peran peneliti adalah sebagai perancang pembelajaran dan pengamat proses pembelajaran, sedangkan guru bertindak sebagai kolaborator yang melaksanakan kegiatan pembelajaran. Peneliti dan guru mata pelajaran bersamasama melakukan evaluasi untuk menentukan kegiatan perbaikan yang akan dilaksanakan. Tahapan yang akan dilalui dalam penelitian tindakan kelas pada dasarnya ada empat, yaitu menyusun rancangan tindakan (Planning), pelaksanaan tindakan (Acting), 
pengamatan (Observing) dan refleksi (Reflecting).

Penelitian tindakan kelas ini dilakukan pada kelas XII Matematika dan Ilmu Alam 1 SMA Negeri 1 Wonosari yang beralamat di Jalan Brigjen Katamso No.4, Wonosari, Gunungkidul, Yogyakarta. Penelitian ini dilaksanakan pada bulan September 2015.

Subjek penelitian ini adalah seluruh siswa kelas XII Matematika dan Ilmu Alam 1 SMA Negeri 1 Wonosari Tahun Ajaran 2015/2016 dengan jumlah siswa sebanyak 30 siswa. Sedangkan objek penelitian ini adalah Aktivitas Belajar Akuntansi Siswa Kelas XII Matematika dan Ilmu Alam 1 SMA Negeri 1 Wonosari Tahun Ajaran 2015/2016.

Menurut Suharsimi Arikunto (2007: 3) ada tiga pengertian yang dapat diterangkan, yaitu : (1) Penelitian, menunjukkan suatu kegiatan mencermati suatu objek dengan menggunakan cara dan aturan metodologi tertentu untuk memperoleh dan atau informasi yang bermanfaat dalam meningkatkan mutu suatu hal; (2) Tindakan, menunjukkan pada sesuatu gerak kegiatan yang sengaja dilakukan dengan tujuan tertentu; (3) Kelas, dalam hal ini tidak terikat pada pengertian ruang kelas, tetapi dalam pengertian yang lebih spesifik. Tahapan yang akan dilalui dalam penelitian tindakan kelas pada dasarnya ada empat, yaitu menyusun rancangan tindakan (Planning), pelaksanaan tindakan (Acting), pengamatan (Observing) dan refleksi (Reflecting). Adapun prosedur penelitian tersebut dapat digambarkan sebagai berikut :

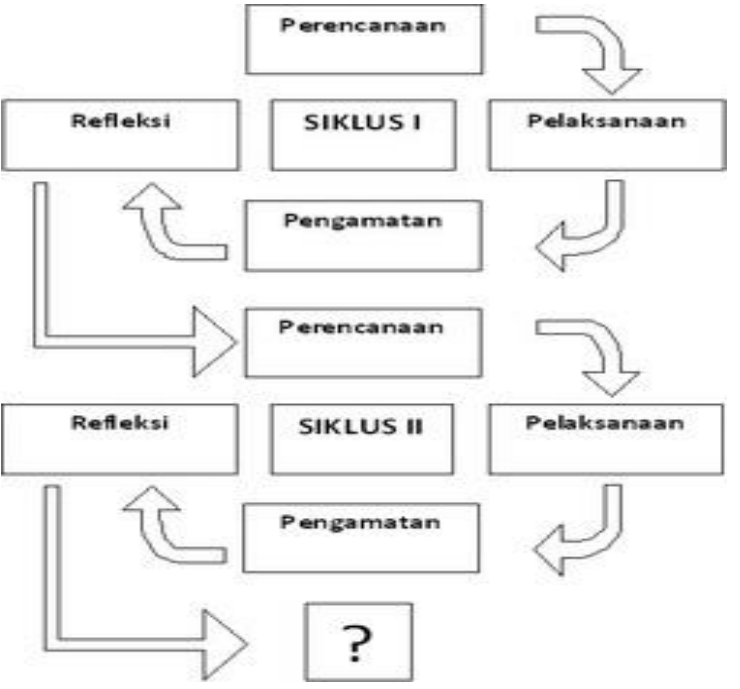

Gambar 1. Desain Penelitian Tindakan Kelas

Data yang diperoleh berupa data kuantitatif hasil pengamatan oleh observer dengan menggunakan pedoman observasi. Teknik pengumpulan data pada penelitian ini yaitu dengan observasi partisipatif dan dokumentasi.

Observasi partisipasi dalam pembelajaran ini dilakukan dengan mengikuti kegiatan proses belajar mengajar untuk memperoleh data seputar pelaksanaan pembelajaran, penggunaan metode pembelajaran, kesesuaian kegiatan belajar mengajar dengan rencana pembelajaran yang telah dirancang, serta mengamati berbagai aktivitas belajar siswa yang muncul selama pembelajaran berlangsung. Dalam penelitian ini disediakan pedoman untuk pelaksanaan observasi serta lembar observasi yang digunakan selama pengamatan.

Pengamat dalam penelitian ini berjumlah dua observer. Dalam permainan teka teki silang ini siswa dibagi menjadi lima kelompok sehingga observer 1 mengamati kelompok satu sampai dengan kelompok tiga sedangkan observer 2 mengamati kelompok empat dan lima. Peran guru dalam penelitian ini adalah melaksanakan proses belajar mengajar dengan menggunakan metode Active Knowledge Sharing pada materi jurnal penyesuaian. Peneliti mengamati aktivitas 
belajar siswa saat proses belajar mengajar berlangsung. Pada saat permainan teka teki silang, siswa dibagi menjadi lima kelompok dengan anggota kelompok masing-masing enam siswa. Sebelum permainan dimulai observer menjelaskan peraturan permainan dan siswa duduk melingkari meja sesuai dengan kelompoknya. Dengan formasi demikian maka observer dapat dengan leluasa mengamati aktivitas siswa selama permainan berlangsung.

Dokumentasi yang digunakan dalam penelitian ini antara lain adalah catatan harian, data keadaan siswa, foto-foto pada saat kegiatan pembelajaran berlangsung, silabus, dan RPP. Catatan harian dibuat pada saat proses tindakan berlangsung. Dalam penelitian ini, tindakan yang dilakukan berkaitan dengan upaya untuk meningkatkan Aktivitas Belajar Akuntansi melalui penerapan Metode Active Knowledge Sharing Berbantu Media Teka Teki Silang.

Instrumen penelitian yang digunakan dalam penelitian ini yaitu lembar observasi dan dokumentasi. Penelitian ini menggunakan lembar observasi yang berisi indikator-indikator aktivitas belajar siswa selama proses pembelajaran menggunakan metode Active Knowledge Sharing berbantu media teka teki silang.

Tabel 1. Indikator Aktivitas Belajar Akuntansi

\begin{tabular}{|c|l|l|l|}
\hline No & Aspek & & Indikator \\
\hline 1 & $\begin{array}{l}\text { Visual } \\
\text { Activities }\end{array}$ & A & $\begin{array}{l}\text { Siswa membaca } \\
\text { materi Akuntansi } \\
\text { yang relevan. }\end{array}$ \\
\cline { 2 - 4 } & B & $\begin{array}{l}\text { Siswa } \\
\text { memperhatikan } \\
\text { penjelasan materi } \\
\text { dari guru. }\end{array}$ \\
\hline 2 & $\begin{array}{l}\text { Oral } \\
\text { Activities }\end{array}$ & C & $\begin{array}{l}\text { Siswa mengajukan } \\
\text { pertanyaan kepada } \\
\text { guru atau teman saat } \\
\text { proses belajar } \\
\text { mengajar. }\end{array}$ \\
\cline { 3 - 4 } & D & $\begin{array}{l}\text { Siswa memberikan } \\
\text { pendapat, saran, } \\
\text { komentar kepada }\end{array}$ \\
\hline
\end{tabular}

\begin{tabular}{|l|l|l|l|}
\hline \multirow{2}{*}{} & & & $\begin{array}{l}\text { guru atau teman } \\
\text { tentang materi yang } \\
\text { sedang dibahas. }\end{array}$ \\
\cline { 3 - 4 } & E & $\begin{array}{l}\text { Siswa berdiskusi } \\
\text { dalam kelompok. }\end{array}$ \\
\hline 3 & Listening & $\mathrm{F}$ & $\begin{array}{l}\text { Siswa mendengarkan } \\
\text { penjelasan guru atau } \\
\text { teman pada saat } \\
\text { proses pembelajaran. }\end{array}$ \\
\hline Activities & $\mathrm{G}$ & $\begin{array}{l}\text { Siswa mencatat } \\
\text { materi oleh } \\
\text { disampaikan } \\
\text { guru. }\end{array}$ \\
\cline { 3 - 4 } & $\mathrm{H}$ & $\begin{array}{l}\text { Siswa mencatat hasil } \\
\text { diskusi. }\end{array}$ \\
\cline { 3 - 4 } & $\mathrm{I}$ & $\begin{array}{l}\text { Siswa menulis } \\
\text { jawaban } \\
\text { permainan teka teki } \\
\text { silang. }\end{array}$ \\
\hline 5 & $\begin{array}{l}\text { Mental } \\
\text { Activities }\end{array}$ & $\mathrm{J}$ & $\begin{array}{l}\text { Siswa menemukan } \\
\text { jawaban yang tepat } \\
\text { dalam mengerjakan } \\
\text { tugas kelompok }\end{array}$ \\
\hline
\end{tabular}

Dokumentasi dalam penelitian ini yaitu berupa catatan harian, data keadaan siswa, foto-foto pada saat kegiatan pembelajaran berlangsung, silabus, dan RPP. Catatan harian dalam penelitian ini digunakan untuk mengamati dan mencatat kejadian-kejadian penting yang terjadi selama proses pembelajaran akuntansi siswa kelas XII Matematika dan Ilmu Alam 1 SMA Negeri 1 Wonosari Tahun Ajaran 2015/2016. 
Tabel 2. Catatan Harian

\section{CATATAN HARIAN}

Nama Sekolah : SMA Negeri 1 Wonosari

Kelas : XII MIA 1

Semester : : 1

\begin{tabular}{|l|c|c|c|}
\hline No. & $\begin{array}{c}\text { Hari, } \\
\text { Tanggal }\end{array}$ & $\begin{array}{c}\text { Jam } \\
\text { ke }\end{array}$ & Keterangan \\
\hline & & & \\
& & & \\
& & & \\
& & & \\
\end{tabular}

Yogyakarta, 21 September 2015 Observer

\section{(Agatha Saputri)}

NIM 12803241014

Teknik analisis data yang digunakan dalam penelitian ini dilakukan secara terus menerus selama pengumpulan data berlangsung sampai akhir penelitian atau penarikan kesimpulan. Dalam penelitian ini dilakukan analisis data deskriptif dengan persentase.

Analisis data berupa data hasil observasi yang diperoleh dengan cara memberikan skor pada setiap indikator yang diamati. Setiap indikator memiliki skor ketercapaian yang dibuat dengan rentang skor 0,1,2. Analisis ini dilakukan dengan :

Mengolah skor Aktivitas Belajar Akuntansi

a. Membuat kategori penskoran untuk Aktivitas Belajar Akuntansi.

b. Menghitung dan menjumlahkan skor untuk masing-masing Aktivitas Belajar Akuntansi yang diamati. c. Menghitung skor Aktivitas Belajar Akuntansi pada setiap aspek yang diamati dengan rumus :

Jumlah skor pada setiap aspek Skor maksimum

(Sugiyono, 2013: 143)

d. Menghitung peningkatan persentase skor siklus Aktivitas Belajar Akuntansi tiap indikator dengan rumus :

1) Peningkatan persentase relatif skor siklus tiap indikator dengan rumus : $\frac{\mathrm{B}-\mathrm{A}}{\mathrm{A}} \times 100 \%$

Keterangan

B = Persentase Skor Siklus II tiap indikator

$\mathrm{A}=$ Persentase Skor Siklus I tiap indikator

2) Peningkatan persentase absolut skor siklus tiap indikator dengan rumus :

$\mathrm{B}-\mathrm{A}$

Keterangan:

$\mathrm{B}=$ Persentase Skor Siklus II tiap indikator

A $=$ Persentase Skor Siklus I tiap indikator

e. Menghitung persentase skor rata-rata Aktivitas Belajar Akuntansi dengan rumus :

\section{Skor Total Aktivitas Belajar \\ Jumlah indikator $\mathrm{x} 100 \%$}

Setelah data mengenai Aktivitas Belajar Akuntansi diolah, data tersebut akan disajikan dalam bentuk tabel dan grafik sehingga mudah dipahami.

Penarikan kesimpulan dilakukan dengan tujuan untuk menjawab rumusan masalah yang telah disampaikan pada bagian awal penelitian. Dalam hal ini dilakukan pemaknaan ke dalam pernyataan. 


\section{HASIL PENELITIAN DAN PEMBA- HASAN}

Hasil penelitian pada siklus I sebagai berikut :

Tabel 3. Aktivitas Belajar Siswa pada Siklus I

\begin{tabular}{|c|c|c|}
\hline No & Indikator yang diamati & $\begin{array}{c}\text { Persentase } \\
\text { Aktivitas } \\
\text { Siswa } \\
\end{array}$ \\
\hline 1 & $\begin{array}{l}\text { Siswa membaca materi } \\
\text { Akuntansi yang relevan }\end{array}$ & $64,17 \%$ \\
\hline 2 & $\begin{array}{l}\text { Siswa memperhatikan } \\
\text { penjelasan materi dari } \\
\text { guru }\end{array}$ & $61,67 \%$ \\
\hline 3 & $\begin{array}{l}\text { siswa mengajukan } \\
\text { pertanyaan kepada guru } \\
\text { atau teman } \\
\text { saat proses belajar } \\
\text { mengajar }\end{array}$ & $65,83 \%$ \\
\hline 4 & $\begin{array}{l}\text { siswa memberikan } \\
\text { pendapat, saran, } \\
\text { komentar kepada } \\
\text { guru atau teman tentang } \\
\text { materi yang sedang } \\
\text { dibahas }\end{array}$ & $68,33 \%$ \\
\hline 5 & $\begin{array}{l}\text { Siswa berdiskusi dalam } \\
\text { kelompok }\end{array}$ & $72,50 \%$ \\
\hline 6 & $\begin{array}{l}\text { Siswa mendengarkan } \\
\text { penjelasan guru atau } \\
\text { teman } \\
\text { pada saat proses } \\
\text { pembelajaran }\end{array}$ & $70,83 \%$ \\
\hline 7 & $\begin{array}{l}\text { Siswa mencatat materi } \\
\text { yang disampaikan oleh } \\
\text { guru }\end{array}$ & $71,67 \%$ \\
\hline 8 & $\begin{array}{l}\text { Siswa mencatat hasil } \\
\text { diskusi }\end{array}$ & $63,33 \%$ \\
\hline 9 & $\begin{array}{l}\text { Siswa menulis jawaban } \\
\text { saat permainan teka-teki } \\
\text { silang }\end{array}$ & $61,67 \%$ \\
\hline 10 & $\begin{array}{l}\text { Siswa menemukan } \\
\text { jawaban yang tepat } \\
\text { dalam mengerjakan tugas } \\
\text { kelompok }\end{array}$ & $70,83 \%$ \\
\hline \multicolumn{2}{|r|}{$\begin{array}{c}\text { Rata-rata aktivitas belajar } \\
\text { siswa }\end{array}$} & $67,08 \%$ \\
\hline
\end{tabular}

Berdasarkan pada tabel di atas, dari 30 siswa di kelas XII Matematika dan Ilmu Alam 1 SMA Negeri 1 Wonosari, indikator aktivitas belajar pada siklus I sebesar $64,17 \%$ siswa membaca materi Akuntansi yang relevan, $61,67 \%$ siswa memperhatikan penjelasan materi dari guru, 65,83\% siswa mengajukan pertanyaan kepada guru atau teman saat proses belajar mengajar, 68,33\% siswa memberikan pendapat, saran, komentar kepada guru atau teman tentang materi yang sedang dibahas, $72,50 \%$ siswa berdiskusi dalam kelompok, 70,83\% siswa mendengarkan penjelasan guru atau teman pada saat proses pembelajaran, 71,67\% siswa mencatat materi yang disampaikan oleh guru, 63,33\% siswa mencatat hasil diskusi, 61,67\% siswa menulis jawaban saat permainan teka teki silang, dan 70,83\% siswa ikut serta dalam mengerjakan tugas kelompok. Dari hasil persentase tersebut dijumlahkan kemudian dibagi dengan banyaknya indikator, maka diperoleh ratarata Aktivitas Belajar siswa pada siklus I sebesar $67,08 \%$. Jumlah tersebut dirasa kurang karena aktivitas siswa selama pembelajaran menggunakan metode Active Knowledge Sharing berbantu media teka teki silang belum mencapai target kriteria keberhasilan peneliti dan guru yaitu $\geq 75 \%$ dari jumlah siswa dalam satu kelas. Untuk menggambarkan skor persentase aktivitas belajar akuntansi siswa, berikut ini disajikan diagram mengenai aktivitas belajar akuntansi siswa berdasarkan tabel: 


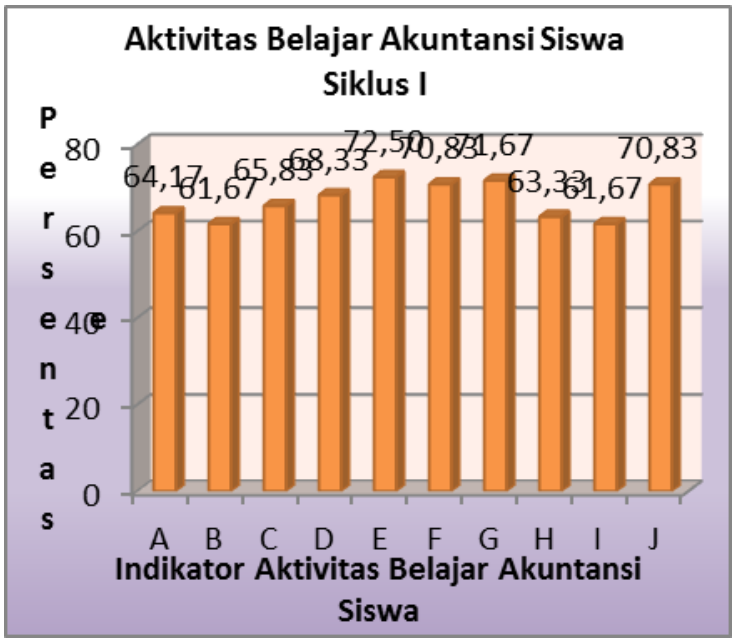

Gambar 1. Diagram Hasil Observasi Siklus I

Hasil penelitian pada siklus II sebagai berikut :

Tabel 4. Aktivitas Belajar Siswa pada Siklus II

\begin{tabular}{|c|l|c|}
\hline No & \multicolumn{1}{|c|}{$\begin{array}{c}\text { Indikator yang } \\
\text { diamati }\end{array}$} & $\begin{array}{c}\text { Persentase } \\
\text { Aktivitas } \\
\text { Siswa }\end{array}$ \\
\hline 1 & $\begin{array}{l}\text { Siswa membaca materi } \\
\text { Akuntansi yang relevan }\end{array}$ & $78,33 \%$ \\
\hline 2 & $\begin{array}{l}\text { Siswa memperhatikan } \\
\text { penjelasan materi dari } \\
\text { guru }\end{array}$ & $87,5 \%$ \\
\hline 3 & $\begin{array}{l}\text { siswa mengajukan } \\
\text { pertanyaan kepada guru } \\
\text { atau teman } \\
\text { saat proses belajar } \\
\text { mengajar }\end{array}$ & $81,67 \%$ \\
\hline 4 & $\begin{array}{l}\text { siswa memberikan } \\
\text { pendapat, saran, } \\
\text { komentar kepada } \\
\text { guru atau teman } \\
\text { tentang materi yang } \\
\text { sedang dibahas }\end{array}$ & $77,5 \%$ \\
\hline 5 & $\begin{array}{l}\text { Siswa berdiskusi dalam } \\
\text { kelompok }\end{array}$ & $85,83 \%$ \\
\hline & $\begin{array}{l}\text { Siswa mendengarkan } \\
\text { penjelasan guru atau } \\
\text { teman } \\
\text { pada saat proses } \\
\text { pembelajaran }\end{array}$ & $\begin{array}{l}\text { Siswa mencatat materi } \\
\text { yang disampaikan oleh }\end{array}$ \\
\hline
\end{tabular}

\begin{tabular}{|c|c|c|}
\hline & guru & \\
\hline 8 & $\begin{array}{l}\text { Siswa mencatat hasil } \\
\text { diskusi }\end{array}$ & $80,83 \%$ \\
\hline 9 & $\begin{array}{l}\text { Siswa menulis jawaban } \\
\text { saat permainan teka } \\
\text { teki silang }\end{array}$ & $88,33 \%$ \\
\hline 10 & $\begin{array}{l}\text { Siswa menemukan } \\
\text { jawaban yang tepat } \\
\text { dalam mengerjakan } \\
\text { tugas kelompok }\end{array}$ & $86,67 \%$ \\
\hline \multicolumn{2}{|c|}{$\begin{array}{c}\text { Rata-rata aktivitas belajar } \\
\text { siswa }\end{array}$} & $83,92 \%$ \\
\hline
\end{tabular}

(sumber: data primer yang diolah)

Data mengenai perhitungan aktivitas belajar siswa pada siklus II dapat dilihat pada lampiran halaman 186. Berdasarkan pada tabel diatas, dari 30 siswa di kelas XII Matematika dan Ilmu Alam 1 SMA Negeri 1 Wonosari, indikator aktivitas belajar pada siklus II sebesar 78,33\% siswa membaca materi Akuntansi yang relevan, $87,50 \%$ siswa memperhatikan penjelasan materi dari guru, $81,67 \%$ siswa mengajukan pertanyaan kepada guru atau teman saat proses belajar mengajar, $77,50 \%$ siswa memberikan pendapat, saran, komentar kepada guru atau teman tentang materi yang sedang dibahas, $85,83 \%$ siswa berdiskusi dalam kelompok, $85,00 \%$ siswa mendengarkan penjelasan guru atau teman pada saat proses pembelajaran, $87,50 \%$ siswa mencatat materi yang disampaikan oleh guru, $80,83 \%$ siswa mencatat hasil diskusi, $88,33 \%$ siswa menulis jawaban saat permainan teka teki silang, dan $86,67 \%$ siswa ikut serta dalam mengerjakan tugas kelompok. Dari hasil persentase tersebut dijumlahkan kemudian dibagi dengan banyaknya indikator, maka diperoleh rata-rata Aktivitas Belajar siswa pada siklus I sebesar 83,92\%. Jumlah tersebut sudah mencapai target yang diinginkan peneliti dan guru yaitu $\geq 75 \%$ dari jumlah siswa dalam satu kelas.

Untuk menggambarkan skor persentase aktivitas belajar akuntansi siswa, berikut ini disajikan diagram mengenai aktivitas belajar akuntansi siswa berdasarkan tabel: 


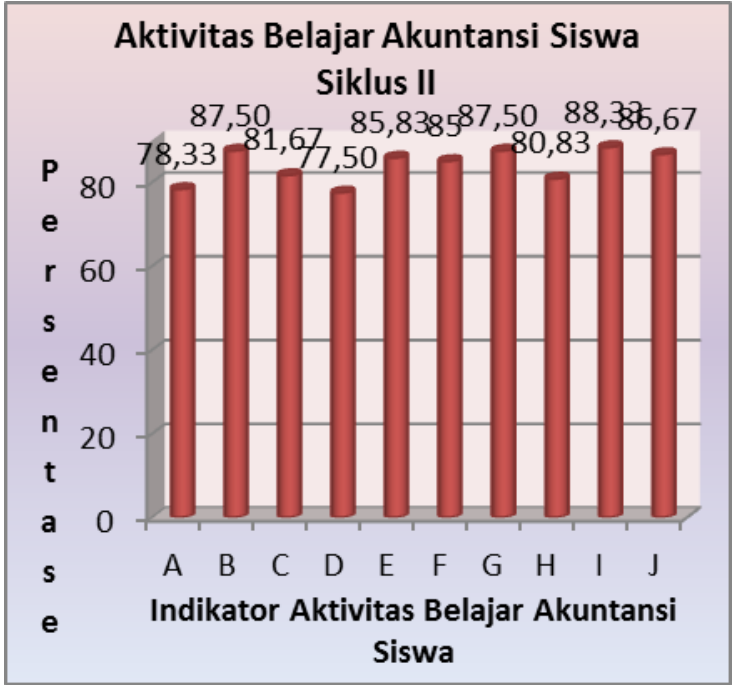

Gambar 2. Diagram Hasil Observasi Siklus II

Hasil penelitian pada siklus II sebagai berikut :

Tabel 5. Aktivitas Belajar Siswa pada Siklus III

\begin{tabular}{|c|l|c|}
\hline No & \multicolumn{1}{|c|}{$\begin{array}{c}\text { Indikator yang } \\
\text { diamati }\end{array}$} & $\begin{array}{c}\text { Persentase } \\
\text { Aktivitas } \\
\text { Siswa }\end{array}$ \\
\hline 1 & $\begin{array}{l}\text { Siswa membaca materi } \\
\text { Akuntansi yang relevan }\end{array}$ & $80,83 \%$ \\
\hline 3 & $\begin{array}{l}\text { Siswa memperhatikan } \\
\text { penjelasan materi dari } \\
\text { guru }\end{array}$ & $\begin{array}{l}88,33 \% \\
\text { siswa mengajukan } \\
\text { pertanyaan kepada guru } \\
\text { atau teman } \\
\text { saat proses belajar } \\
\text { mengajar }\end{array}$ \\
\hline 4 & $\begin{array}{l}\text { siswa memberikan } \\
\text { pendapat, saran, } \\
\text { komentar kepada } \\
\text { guru atau teman tentang } \\
\text { materi yang sedang } \\
\text { dibahas }\end{array}$ & $84,17 \%$ \\
\hline 5 & $\begin{array}{l}\text { Siswa berdiskusi dalam } \\
\text { kelompok }\end{array}$ & $89,17 \%$ \\
\hline 6 & $\begin{array}{l}\text { Siswa mendengarkan } \\
\text { penjelasan guru atau } \\
\text { teman } \\
\text { pada saat proses } \\
\text { pembelajaran }\end{array}$ & $86,67 \%$ \\
\hline
\end{tabular}

\begin{tabular}{|c|c|c|}
\hline 7 & $\begin{array}{l}\text { Siswa mencatat materi } \\
\text { yang disampaikan oleh } \\
\text { guru }\end{array}$ & $90,83 \%$ \\
\hline 8 & $\begin{array}{l}\text { Siswa mencatat hasil } \\
\text { diskusi }\end{array}$ & $84,17 \%$ \\
\hline 9 & $\begin{array}{l}\text { Siswa menulis jawaban } \\
\text { saat permainan teka teki } \\
\text { silang }\end{array}$ & $89,17 \%$ \\
\hline 10 & $\begin{array}{l}\text { Siswa menemukan } \\
\text { jawaban yang tepat } \\
\text { dalam mengerjakan } \\
\text { tugas kelompok }\end{array}$ & $88,33 \%$ \\
\hline \multicolumn{2}{|r|}{$\begin{array}{c}\text { Rata-rata aktivitas belajar } \\
\text { siswa }\end{array}$} & $86,00 \%$ \\
\hline
\end{tabular}

(sumber: data primer yang diolah)

Data mengenai perhitungan aktivitas belajar siswa pada siklus III dapat dilihat pada lampiran halaman 186. Berdasarkan pada tabel di atas, dari 30 siswa di kelas XII Matematika dan Ilmu Alam 1 SMA Negeri 1 Wonosari, indikator aktivitas belajar pada siklus III sebesar 80,83\% siswa membaca materi Akuntansi yang relevan, 88,33\% siswa memperhatikan penjelasan materi dari guru, $84,17 \%$ siswa mengajukan pertanyaan kepada guru atau teman saat proses belajar mengajar, $79,17 \%$ siswa memberikan pendapat, saran, komentar kepada guru atau teman tentang materi yang sedang dibahas, $86,67 \%$ siswa berdiskusi dalam kelompok, $88,33 \%$ siswa mendengarkan penjelasan guru atau teman pada saat proses pembelajaran, $90,83 \%$ siswa mencatat materi yang disampaikan oleh guru, 84,17\% siswa mencatat hasil diskusi, 89,17\% siswa menulis jawaban saat permainan teka teki silang, dan $88,33 \%$ siswa ikut serta dalam mengerjakan tugas kelompok. Dari hasil persentase tersebut dijumlahkan kemudian dibagi dengan banyaknya indikator, maka diperoleh rata-rata Aktivitas Belajar siswa pada siklus III sebesar $86,00 \%$. Jumlah tersebut sudah mencapai target yang diinginkan peneliti dan guru yaitu $75 \%$ dari jumlah siswa dalam satu kelas.

Untuk menggambarkan skor persentase aktivitas belajar akuntansi siswa, berikut ini disajikan diagram mengenai 
aktivitas belajar akuntansi siswa berdasarkan tabel :

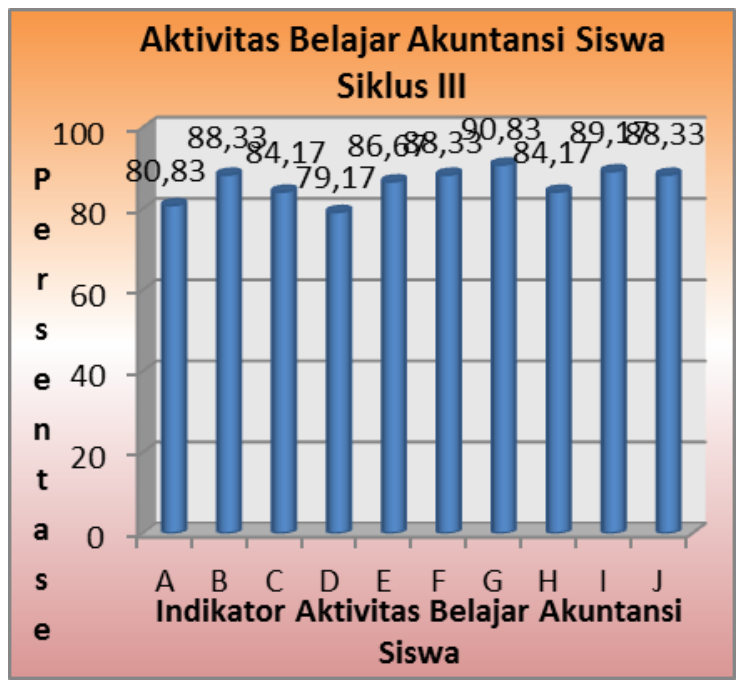

Gambar 3. Diagram Hasil Observasi Siklus III

Pembahasan aktivitas belajar Akuntansi siswa. pada siklus I belum bisa dikatakan optimal karena dilihat dari aktivitas belajar siswa masih ada yang tidak memperhatikan penjelasan guru, berbicara dengan temannya, siswa masih tidak mau bertanya dan menyampaikan pendapat kepada guru. Siswa juga masih enggan untuk mencatat materi yang disampaikan oleh guru. Refleksi pada siklus I dilakukan untuk perbaikan pada pelaksanaan tindakan siklus II. Perbaikan yang dilakukan adalah memberi petunjuk yang jelas kepada siswa, memotivasi siswa untuk berperan aktif dalam mengerjakan tugas kelompok, memberi pemahaman tujuan permainan, dan membuat variasi soal pada teka teki silang sesuai dengan materi yang dipelajari. Melalui perbaikan aktivitas belajar siswa kelas XII Matematika dan Ilmu Alam 1 SMA Negeri 1 Wonosari mengalami peningkatan dari siklus I ke siklus II sebesar $16,83 \%$ yaitu dari $67,08 \%$ menjadi $83,92 \%$ dan diperkuat dengan peningkatan dari siklus II ke siklus III sebesar $2,08 \%$ yaitu dari $83,92 \%$ menjadi $86 \%$. Hal ini sesuai dengan pendapat Wina Sanjaya (2011: 143) bahwa faktor yang mempengaruhi keberhasilan penerapan pembelajaran berbasis aktivitas peserta didik adalah penerapan metode pembelajaran dan media belajar yang tepat. Penggunakan metode Active Knowledge Sharing berbantu media teka teki silang dalam penelitian ini mampu memberikan stimulus.

Data mengenai peningkatan aktivitas belajar akuntansi siswa dengan Penerapan metode Active Knowledge Sharing berbantu media teka teki silang pada kompetensi akuntansi perusahaan jasa kelas XII Matematika dan Ilmu Alam 1 SMA Negeri 1 Wonosari dapat dilihat pada gambar berikut ini :

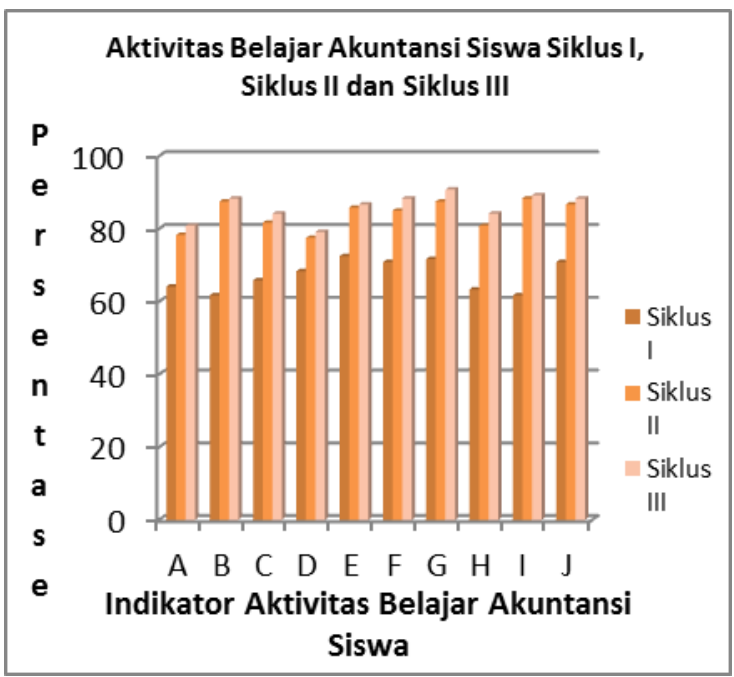

(sumber: data primer yang diolah)

\section{Gambar 4. Peningkatan Aktivitas Belajar Akuntansi Siswa pada Siklus 1, Siklus II, dan Siklus III}

Berdasarkan data di atas, aktivitas belajar siswa dalam membaca materi meningkat yaitu ditunjukkan pada siklus I sebesar $64,17 \%$ menjadi $78,33 \%$ pada siklus II. Diperkuat dengan siklus III mengalami peningkatan sebesar 2,50\% sehingga menjadi 80,83\%. Peningkatan ini dikarenakan pada siklus II maupun III soal dalam teka teki silang merupakan materi yang dipelajari saat proses pembelajaran sehingga mendorong siswa untuk mempelajari materi.

Partisipasi siswa dalam memperhatikan penjelasan materi dari guru mengalami peningkatan dari siklus I sebesar $61,67 \%$ menjadi $87,50 \%$ pada siklus II dan meningkat menjadi $88,33 \%$ pada siklus III. 
Peningkatan ini dikarenakan siswa mulai merasa senang dengan metode Active Knowledge Sharing yang diterapkan selama pembelajaran.

Keaktifan siswa dalam mengajukan pertanyaan kepada guru atau teman pada saat proses belajar mengajar mengalami peningkatan dari siklus I sebesar $65,83 \%$ menjadi $81,67 \%$ pada siklus II dan pada siklus III menjadi $84,17 \%$. Peningkatan ini terjadi karena soal-soal teka teki silang pada siklus II maupun III menggunakan materi yang dipelajari saat proses belajar mengajar sehingga mendorong siswa untuk mengajukan pertanyaan.

Keaktifan siswa memberikan pendapat, saran atau komentar kepada guru atau teman tentang materi yang sedang dibahas pada siklus I sebesar $68,33 \%$ meningkat menjadi $77,50 \%$ pada siklus II. Hal ini diperkuat dengan meningkatnya keaktifan siswa memberikan pendapat pada siklus III menjadi $79,17 \%$. Pada aspek mengemukakan pendapat dalam diskusi mengalami peningkatan karena dengan mengeluarkan pendapat akan memberikan alternatif-alternatif jawaban sehingga mempermudah dalam menemukan jawaban yang tepat.

Partisipasi siswa dalam berdiskusi mengalami peningkatan dari siklus I sebesar $72,50 \%$ menjadi sebesar $85 \%$ pada siklus II. Peningkatan ini diperkuat dengan meningkatnya partisipasi siswa dalam berdiskusi menjadi $86,67 \%$ pada siklus III. Hal ini terjadi karena guru menjelaskan peraturan permainan teka teki silang dengan baik dan jelas kepada siswa sehingga siswa paham dan aktif dalam berdiskusi.

Partisipasi siswa dalam mendengarkan penjelasan guru atau teman pada saat proses pembelajaran mengalami peningkatan dari siklus I sebesar 70,83\% menjadi $85 \%$ pada siklus II dan $88,33 \%$ pada siklus III. Berdasarkan data yang diperoleh dari angket mengenai penerapan metode Active Knowledge Sharing berbantu media teka teki silang, peningkatan ini dikarenakan siswa senang dan tertarik dengan penerapan metode Active Knowledge Sharing yang digunakan oleh guru saat proses belajar mengajar sehingga siswa antusias mendengarkan.

Keaktifan siswa dalam mencatat materi yang disampaikan oleh guru mengalami peningkatan dari $71,67 \%$ pada siklus I menjadi $87,50 \%$ pada siklus II dan $90,83 \%$ pada siklus III. Hal ini dikarenakan siswa mulai mengerti bahwa materi yang disampaikan oleh guru nantinya dapat digunakan sebagai bahan belajar sehingga siswa menjadi aktif untuk mencatat materi yang disampaikan oleh guru.

Partisipasi siswa dalam mencatat hasil diskusi mengalami peningkatan dari 63,33\% pada siklus I menjadi $80,83 \%$ pada siklus II dan $84,17 \%$ pada siklus III. Hal ini dikarenakan siswa mulai tertarik menemukan jawaban dalam permainan teka teki silang pada siklus II dan III sehingga sebagian besar siswa mencatat hasil diskusi.

Keaktifan siswa dalam menulis jawaban saat permainan teka teki silang mengalami peningkatan dari $61,67 \%$ pada siklus I menjadi $88,33 \%$ pada siklus II dan $89,17 \%$ pada siklus III. Peningkatan ini dikarenakan guru menjelaskan aturan permainan teka teki silang dengan jelas sehingga siswa terdorong untuk mengerjakan secara kelompok dan menulis jawaban saat permainan teka teki silang.

Keaktifan siswa dalam menemukan jawaban yang tepat dalam mengerjakan tugas kelompok berupa teka teki silang mengalami peningkatan dari $67,08 \%$ pada siklus I menjadi $86,6 \%$ pada siklus II dan $88,33 \%$ pada siklus III. Hal ini dikarenakan siswa mulai tertarik dengan permainan teka teki silang dan tertantang untuk mencari jawaban yang tepat. Siswa secara bergiliran menjawab pertanyaan-pertanyaan pada permainan teka-teki silang. Siswa menjawab pertanyaan pada permainan teka teki silang dan menjelaskan jawaban pada teman dalam satu kelompok.

Hasil penelitian ini menunjukkan bahwa terdapat peningkatan aktivitas belajar dengan penerapan metode Active Knowledge 
Sharing berbantu media teka teki silang. Hal ini ditunjukkan pada aktivitas belajar siswa pada siklus I sebesar $67,08 \%$ pada pelaksanaan tindakan siklus II meningkat menjadi $83,92 \%$ dan hal ini diperkuat dengan meningkatnya aktivitas belajar siswa pada siklus III menjadi sebesar $86 \%$. Peningkatan tersebut telah mencapai indikator keberhasilan yang diharapkan yaitu $\geq 75 \%$ dari jumlah siswa dalam satu kelas telah aktif selama proses pembelajaran dengan penerapan metode Active Knowledge Sharing berbantu media teka teki silang. Hasil penelitian ini membuktikan hipotesis bahwa penerapan metode Active Knowledge Sharing berbantu media teka teki silang dapat meningkatkan aktivitas belajar pada kompetensi akuntansi perusahaan jasa siswa kelas XII SMA Negeri 1 Wonosari tahun ajaran 2015/2016.

\section{SIMPULAN DAN SARAN Simpulan}

Penerapan metode Active Knowledge Sharing berbantu media teka teki silang dapat meningkatkan aktivitas belajar pada kompetensi akuntansi perusahaan jasa siswa kelas XII SMA Negeri 1 Wonosari Tahun Ajaran 2015/2016. Data hasil rata-rata keseluruhan yang diperoleh dari observasi menunjukkan bahwa terjadi peningkatan rata-rata aspek aktivitas belajar siswa pada siklus I sebesar 67,08\% kemudian meningkat menjadi $83,92 \%$ pada siklus II dan diperkuat meningkat menjadi $86 \%$ pada siklus III.

Berdasarkan catatan harian siswa kelas XII Matematika dan Ilmu Alam 1 SMA Negeri 1 Wonosari tahun ajaran 2015/2016 menunjukkan perubahan positif sikap siswa terhadap penerapan metode Active Knowledge Sharing berbantu media teka teki silang. Hal ini ditunjukkan pada siklus I terdapat empat siswa yang tidak memperhatikan selama guru menjelaskan bahkan ada siswa yang tidur, namun pada siklus II dan Siklus III siswa memperhatikan penjelasan guru dan aktif dalam permainan teka teki silang. Siswa bersemangat dalam proses pembelajaran dengan diterapkannya metode Active Knowledge Sharing berbantu media teka teki silang karena dapat menciptakan suasana kelas yang aktif. Selain itu, siswa tidak cepat bosan selama mengikuti pembelajaran. Siswa dapat mendengarkan penjelasan materi dari guru dan dapat mengungkapan pendapat maupun komentar kepada guru dan teman sehingga terjalin komunikasi dalam

Berdasarkan catatan harian juga menunjukkan peningkatan aktivitas belajar akuntansi siswa. Hal ini ditunjukkan dengan meningkatnya partisipasi siswa dalam proses pembelajaran, menurunnya jumlah siswa yang mengantuk pada saat pembelajaran dan pada siklus terakhir siswa terlihat antusias terhadap pembelajaran dengan penerapan metode Active Knowledge Sharing berbantu media teka teki silang. Berdasarkan angket mengenai penerapan metode Active Knowledge Sharing berbantu media teka teki silang, menunjukkan bahwa siswa senang dan bersemangat saat mengerjakan permainan teka teki silang dan berpartisipasi dalam diskusi.

\section{Saran}

Peneliti lain diharapkan dapat mengembangkan penelitian tindakan kelas yang lebih mendalam pada kompetensi lain, sehingga dapat memberikan sumbangan wawasan di bidang pendidikan. Peneliti lain sebaiknya mempersiapkan dengan matang dan membuat pengelolaan waktu yang baik. Agar data yang diperoleh lebih baik lagi sebaiknya observer lebih dari dua.

\section{DAFTAR PUSTAKA}

Fenti Noor Endah Kurniawati. "Implementasi Model Active Learning dengan Teknik Learning Starts With A Question untuk Meningkatkan Aktivitas Belajar Akuntansi Peserta Didik Kelas XI IPS 3 SMA Negeri 5 Yogyakarta Tahun Ajaran 2013/2014". Skripsi. Yogyakarta: Universitas Negeri Yogyakarta. 
Hamruni. (2012). Strategi Pembelajaran. Yogyakarta: Insan Madani.

Heru Kurniawan. (2015). 30 Permainan Kreatif untuk Meningkatkan Kecerdasan Anak. Yogyakarta: KATAHATI.

Ika Nursanti. (2014). "Penerapan Metode Pembelajaran Kooperatif Tipe Teams Games Tournament (TGT) dengan Bantuan Media Teka-teki Silang untuk Meningkatkan Keaktifan Belajar Akuntansi Siswa Kelas X Akuntansi SMK Kristen 2 Klaten Tahun Ajaran 2013/2014".Skripsi.Yogyakarta : Fakultas Ekonomi Universitas Negeri Yogyakarta

Oemar Hamalik. (2003). Proses Belajar Mengajar. Jakarta: PT Bumi Aksara.

Sardiman A.M. (2011). Interaksi dan Motivasi Belajar Mengajar. Jakarta: Rajawali.

Sugiyono. (2013). Metode Penelitian Kualitatif Kuantitatif, Kualitatif, dan $R \& D$. Bandung: Alfabeta.

Suharsimi Arikunto. (2007). Penelitian Tindakan Kelas. Jakarta: PT Bumi Aksara.

(2013). Prosedur Penelitian, Suatu Pendekatan Praktik. Jakarta: PT Rineka Cipta.

Yeni Amnesti. (2013). "Penerapan Metode Active Knowledge Sharing untuk Meningkatkan Motivasi Belajar IPA Kelas IV Sekolah Dasar Negeri 03 Ngargoyoso Kabupaten Karanganyar Tahun Pelajaran 2012/2013". Skripsi. Surakarta: Fakultas Kegunaan dan Ilmu Pendidikan Universitas Muhammadiyah Surakarta.
Zainal Arifin \& Adhi Setiyawan. (2012). Pengembangan Pembelajaran Aktif dengan ICT. Yogyakarta: PT. Skripta Media Creative.

Evaluasi Pembelajaran. Bandung: PT Remaja Rosdakarya Offset. 